\title{
Prihodnja osvetlitev in nočna podoba mest: študija primera
}

Prihodnja osvetlitev na podlagi polprevodniških virov svetlobe bo spremenila nočno podobo mest. Možnosti njihove umestitve in uporabe $\mathrm{v}$ urbanem prostoru so številne. $V$ članku zato proučujemo, ali bi njihova prihodnja uporaba v splošni zunanji razsvetljavi pozitivno vplivala na človekovo sprejemanje tako osvetljenega urbanega prostora. Na podlagi inovativne uporabe omenjenih virov svetlobe smo izoblikovali dva različna koncepta osvetlitve. Prvi koncept temelji na ploskovni osvetlitvi, drugi pa na detajlnem prikazu arhitekturno-urbanih elementov. Predlogi za osvetlitev so bili narejeni na petih različnih lokacijah mesta. Poleg izpolnjevanja funkcionalnih potreb upoštevajo tudi urbanistični in arhitekturni vidik osvetljevanja. $\mathrm{Z}$ ocenami afektivne kakovosti slikovnih prikazov smo predstavili in proučevali temeljna afektivna stanja anketiranih. Ugotovitve kažejo, da so se anketiranci pri večini predlogov strinjali pri ocenah spremenljivk »prijetnost « in » pozornost. Statistika pokaže med konceptoma značilne razlike pri ocenah obeh spremenljivk. Pri neposredni primerjavi obeh konceptov smo ugotovili, da je naklonjenost anketirancev do določenega osvetlitvenega koncepta odvisna tudi od mestne lokacije. S člankom želimo poudariti pomen nočne podobe mesta pri razvoju prihodnjih strategij osvetlitve, ki temeljijo na polprevodniških virih svetlobe.

Ključne besede: LED, OLED, oblikovanje osvetlitve, nočna podoba urbanih prostorov, Ljubljana 


\section{Uvod}

Kakovostna zunanja razsvetljava in svetlobna signalizacija sta ključni pri ureditvi modernih urbanih okolij ponoči in tudi podnevi. Pri sodobnem oblikovanju mestne osvetlitve govorimo o celostnem načrtovanju osvetlitve. Pri tem ob funkcionalnih zahtevah ni pomembno le vprašanje stroškov, vzdrževanja, svetlobnega onesnaženja in porabe energije, temveč tudi arhitekturnih, estetskih in čustvenih vrednot. Vidljivost je sicer pogoj za kakovostno osvetlitev, vendar so dolgo dajali poudarek le njej in zanemarjali druge potrebe. Diana Joels (2006) razlaga, da prihaja v ospredje želja po ustvarjanju harmonične, okoljsko čim ustreznejše in kontekstualno čutne osvetlitve. Po trajnostnih načelih naj bi poleg okoljsko-ekonomskih vidikov osvetlitve med drugim upoštevali tudi estetsko izboljšanje videza prostora, vzpostavitev družbenih stikov in dobrega počutja prebivalcev mest (Casciani in Rossi, 2012). S tako imenovanimi polprevodniškimi viri svetlobe oziroma tehnologijo SSL (ang. Solid State Lighting), v katero spadajo tudi anorganske svetleče diode LED (angl. Light Emitting Diode) in organske svetleče diode OLED (ang. Organic Light Emitting Diode), naj bi v bližnji prihodnosti laže reševali celostno problematiko urbane osvetlitve. Ta tehnologija svetil ima velik potencial zaradi svojih tehničnih značilnosti, energetske učinkovitosti in svojega še vedno hitrega razvoja. Nove možnosti umestitve svetil LED in OLED v grajeno strukturo mesta ponujajo tudi dodatno funkcionalnost in oblikujejo nove oblikovalske okvire. Medtem ko se delež svetil v mestni razsvetljavi na podlagi tehnologije LED v zadnjih letih hitro povečuje, bo do začetka množičnejše uporabe svetil OLED v urbanem prostoru minilo še nekaj let. Možnosti uporabe LED- in OLED-svetil so številne. Te vključujejo inovativno umestitev v grajeno strukturo mesta, nove kombinacije namembnosti svetil, prilagajanje vremenskim razmeram in prisotnosti uporabnikov, interaktivnost ter nove aplikacije za informacijske, orientacijske in dekorativne namene. Nočna podoba mest se lahko zaradi tega močno spremeni. Glavno vprašanje, na katero želimo odgovoriti v članku, je, ali bi prihodnje možnosti uporabe LED- in OLED-svetil pri splošni zunanji mestni osvetlitvi pozitivno vplivale na človekovo sprejemanje podobe tako osvetljenega prostora. $\mathrm{V}$ ta namen smo izoblikovali ploskovni in detajlni koncept prihodnje osvetlitve in ju slikovno predstavili na študiji primera, in sicer na petih lokacijah v Ljubljani. Preveriti želimo tudi, ali je določen koncept osvetlitve na izbrani lokaciji prijetnejši in ali pritegne večjo pozornost kot drugi. V članku nato proučimo še mnenje anketiranih o estetskem ugajanju predlagane osvetlitve, o vidni orientaciji v prikazanem prostoru in primernosti osvetlitvenih predlogov glede na izbrano lokacijo. Ob tem iščemo smernice za čim bolj smiselno umestitev LED- in OLED-svetil v mestni prostor. Raziskave osvetlitve urbanih prostorov $s$ fotografijami se izvajajo tudi v novejšem času, vendar se nanašajo predvsem na obstoječe možnosti osvetlitve (Ünver, 2009, ter Casciani in Rossi, 2012). V zadnjem času je veliko raziskav, v katerih se proučujejo različni elementi človekovega zaznavanja $\mathrm{v}$ zunanjem prostoru ponoči (Johansson idr., 2011), primerjajo pa se tudi različni viri svetlobe (Rea idr., 2009). V raziskavah LED-svetil se proučujejo zaznavanje kakovosti svetlobe, vidna dostopnost (ang. visual accessibility) in občutenje nevarnosti z uporabo LED-nadomestkov (ang. LED retrofits) v obstoječih svetilih (Kuhn idr., 2013), primerjajo pa se tudi viri LED z uveljavljenimi viri svetlobe (glej npr. Kostic idr., 2013). Vendar pa se prihodnjim možnostim uporabe polprevodniških svetil in zaradi tega spremenjene podobe urbanega prostora ne posveča veliko pozornosti. S člankom poskušamo zapolniti to raziskovalno vrzel in proučiti vpliv takih sprememb na podobo mesta. Ob tem obravnavamo tudi raznovrstno problematiko take umestitve LED- in OLED-svetil v prostor. Hkrati želimo opozoriti, da je treba pri prehodu na nove tehnologije svetil sočasno razmisliti tudi o pomenu nočne podobe mest. $\mathrm{V}$ članku najprej na kratko predstavimo arhitekturne in urbanistične vidike osvetlitve, opišemo LED- in OLED-svetila in vplive prikazov osvetlitve na čustvene odzive ljudi. Nato se osredotočimo na raziskovalne metode in oris prihodnjih osvetlitvenih predlogov. Predstavitvi rezultatov sledi razprava o tem, ali so predlagane rešitve upravičene in sprejemljive, $\mathrm{v}$ njej pa podamo tudi smernice za nadaljnje raziskave.

\section{Teoretična izhodišča}

\subsection{Arhitekturno urbanistični vidik osvetlitve mest}

Zunanja razsvetljava se v literaturi običajno deli na funkcionalno za namen vidljivosti in varnosti in na razsvetljavo za ustvarjanje primernega videza mesta. Mestni prostori se ob večerih, tudi do poznih nočnih ur, vse bolj uporabljajo za številne kulturne, socialne, športne in zabavne aktivnosti, za katere so ljudje podnevi zaradi dela prikrajšani. Nočni značaj mesta se pri uporabi umetne osvetlitve ne bi smel izgubiti. Osvetlitev mest naj bi ljudi v mesta tudi privabljala, jih usmerjala in očarala (Brandi in Geissmar-Brandi, 2007). Ulrike Brandi in Christoph Geissmar-Brandi (2007) menita, da je osnovni arhitekturno-urbanistični vidik pri osvetljevanju mesta zamisel drugačnega nočnega mesta. Svetloba je po navadi to, kar nam omogoči, da doživljamo prostor, oblikovanje osvetlitve pa je s tem pomembna arhitekturna sestavina. Joels (2006) poudari, da je svetloba močno orodje za izboljšanje vloge vidnih doživetij v urbanem kontekstu. Namen urbane osvetlitve je med drugim vzpostavitev ključnih značilnosti mestne identitete, ki danes postaja vse manj gotova. Primerna osvetlitev je tudi eden ključnih principov ustvarjanja trajnostnih uličnih krajin (ang. sustainable streetscape) (Rehan, 2013). Alexander Schmidt in Martin Töllner (2006) pojasnita, da lahko s svetlobo namensko izključujemo tisto, kar v prostoru ni lepo ali je narobe postavljeno, s tem pa pridobi nočna slika mesta tudi 
pozitiven psihološki učinek. Tomaž Novljan (2008: 90) s terminom »svetlobno degradiran ambient « označuje posebno prostorsko raven $\mathrm{v}$ arhitekturi, na kateri neustrezna osvetlitev škoduje zaznavi in uporabi sicer kakovostnega dela grajenega prostora. Po njegovem mnenju na oblikovanje kakovostnega svetlobnega ambienta vpliva tudi premočna oziroma preveč enakovredna osvetljenost kakovostnih arhitekturnih elementov in sklopov, ki lahko pomeni njihovo degradacijo. Pri tem so pomembne tudi odbita svetloba, sence, struktura, teksture in barve osvetljenih objektov (Novljan, 2008). Urbana osvetlitev naj bi se skladala $s$ celostnim načrtom osvetlitve mesta (ang. urban lighting master plan). Ta naj bi združeval inovativnost in trajnostne energetske politike $\mathrm{z}$ estetskim izboljšnjem urbanega okolja, pri čemer je zelo pomembno upoštevanje okoljskih dejavnikov (Schmidt in Töllner, 2006). Širše tu že lahko govorimo o splošnih izzivih urbanega menedžmenta (glej na primer Bačlija, 2011).

\subsection{Svetila LED in OLED}

Tehnologiji virov svetlobe OLED in LED temeljita na polprevodnikih, vendar omogočata različne svetlobne učinke. Posamezni čipi LED-vira svetlobe so običajno majhni. Za uporabo v splošni razsvetljavi komponente LED združujemo v sistem, za to pa običajno potrebujemo tudi ustrezno optiko. Osnovne OLED-komponente so dimenzijsko večje in izsevajo svetlobo »ploskovno «. Čeprav sta tehnologiji danes komplementarni, se lahko zgodi, da si bosta nekega dne konkurirali (Hohl-Abi Chedid, 2012). Obe obljubljata manjšo porabo energije, manj vzdrževanja in spremembo celotne infrastrukture razsvetljave. Tehnologija polprevodniških virov svetlobe prinaša zamisel o novi »digitalni svetlobni paradigmi « (Kennedy, 2005). Ta tako ni več del »žarnične kulture« osvetljevanja, temveč ponuja nov digitalni model svetlobe. $Z$ njim se spremeni razmerje med svetlobo in informacijo. To se razlikuje od kategorij, ki so jih ustvarile oblikovalske stroke, in ponuja nov način razmišljanja o predstavi, ki jo imamo o materialih. Inovativna umestitev polprevodniških virov svetlobe v urbani prostor omogoča tudi prepletanje funkcionalne razsvetljave in razsvetljave za izboljšanje podobe mesta. Poznavanje njihovih značilnosti je zelo pomembno za učinkovito in okolju sprejemljivo umestitev v urbani prostor. LED-tehnologija svetil je že dosegla zrelo stopnjo svojega razvoja. Napovedi za tržni delež LED-svetil v zunanji razsvetljavi kažejo, da naj bi se ta na območju Evrope, Azije in Severne Amerike s $6 \%$ v letu 2011 povečal na več kot $70 \%$ v letu 2020 (McKinsey, 2012). Za OLED-svetila so napovedi različne. Njihov razvoj za splošno razsvetljavo je v intenzivni fazi, napovedovanje njihove prihodnosti pa je precejšen izziv (glej na primer Parandian in Rip, 2013). Nekateri predvidevajo do leta 2020 le postransko vlogo OLED-svetil v splošni razsvetljavi, drugi pa za takrat napovedujejo začetek njihove široke uporabe na vseh področjih. Pri OLED-svetilih gre za aktivne organske plasti, ki potrebujejo za svoje delovanje napajalno elektroniko na podlagi tankoslojnih tranzistorjev. Uporaba tehnologije na gibljivih substratih pomeni možnost izdelave tankih, upogibljivih in prosojnih virov svetlobe. Taka svetila so lahko vgrajena tudi v materiale oziroma arhitekturne površine. Pri tem je zelo pomemben razvoj tehnologije za doseganje enakomerne svetlosti OLED-svetil (Slawinski idr., 2013). Poudarek je tudi na študijah modelov mehanskih karakteristik upogljivih svetil (glej Chiang idr., 2009), raziskavah optičnih značilnosti prosojnih svetil OLED (Lee idr., 2011) in ustreznem hlajenju pri njihovem delovanju (glej na primer Schwamb idr., 2013). Kisik in vlaga v zraku povzročata hitro degradacijo svetil OLED, zato je zelo pomembna ustrezna zašcita organskih plasti. Pri tem ima precejšen potencial nanašanje ustreznih dodatnih tankih organskih plasti z metodo vakuumskega termičnega izhlapevanja (Grover idr., 2011). $\mathrm{V}$ bližnji prihodnosti bodo svetilom LED in OLED morda komplementarna tudi svetila, ki temeljijo na polprevodniški laserski tehnologiji. Z njimi bi lahko dosegli velike svetlobne izkoristke tudi pri precej večjih gostotah električnega toka, kot jih je mogoče doseči s svetili LED in OLED. Da bi bilo mogoče z laserji različnih valovnih dolžin svetlobe kljub ozkim širinam spektralnih črt ustvariti kakovostno belo svetlobo za splošno osvetlitev, potrjujejo tudi poskusi (Neumann idr., 2011).

\subsection{Proučevanje vplivov osvetlitve na čustvene odzive ljudi}

Interakcija med fizičnim okoljem in ljudmi je odvisna od značilnosti posameznika. Cirkumpleksni model čustvenih stanj (ang. circumplex model of affect), ki ga je James A. Russell (1980) razvil kot ogrodje za proučevanje vplivov okolja na čustvene odzive, predvideva, da so afektivni doživljaji oziroma čustvena stanja najbolje označeni z dvema glavnima dimenzijama: z vzbujanjem (ang. arousal) in valentnostjo (ang. valence). Po Russllu (2003) je prvi elementarni temelj v psihološki razlagi čustev temeljni afekt. To je nevrofiziološko stanje, ki ga človek doživlja zavestno v danem trenutku, je preprosto in nereflektivno. Iz teh temeljnih čustvenih stanj nastanejo čustva. Stopnja valentnosti sega od visoko pozitivne do visoko negativne, stopnja vzbujanja pa od pomirjajočega oziroma umirjenega do razburljivega. Strukturo čustvenih stanj tukaj predstavimo v geometrijskem prostoru z dvodimenzionalno mrežo, pri čemer na osi nanašamo stopnjo vzbujanja in raven prijetnosti. Zaznavanje prijetnih oziroma neprijetnih in vzbujajočih oziroma nevzbujajočih značilnosti zunanjih dražljajev (stimulansov), kot so objekti, kraji in dogodki, je po Russllu (2003) drugi elementarni temelj v psihološki razlagi čustev. To poimenuje zaznavanje afektivne kakovosti (ang. perception of affective quality). Medtem ko so temeljni afekti notranja čustvena stanja posamezne osebe, je afektivna kakovost značilnost dražljaja, ki zmore povzročiti spremembo $\mathrm{v}$ temeljnem afektu. Afektivno 
kakovost po navadi merimo z enakima dimenzijama kot temeljni afekt. Ahmet Ünver (2009) povzame, da je osvetlitev eden najpomembnejših dejavnikov pri ustvarjanju podobe človeško zgrajenih okolij, ki vpliva na človeško doživljanje urbanega prostora (Mahnke, 1987; Narboni, 2004, in Ritter, 2006). Rikard Küller idr. (2006) ugotavljajo, da na razpoloženje ljudi bolj kot objektivno merjene razlike $\mathrm{v}$ osvetljenosti vpliva subjektivna kakovost osvetlitve. Že v 70. letih 20. stoletja so bili razviti psihološki postopki za ocenjevanje subjektivnih občutkov in izkustev v raziskovanju osvetlitve ter uporaba različnih metod ocenjevanja, kot so na primer semantične diferencialne lestvice (Flynn idr., 1979). Maria Johansson idr. (2011) poudarijo, da sta subjektivna ocena svetlosti in zaznana stopnja prijetnosti oziroma neprijetnosti osvetljenega prostora glavna elementa pri raziskovanju subjektivne kakovosti osvetlitve. $\mathrm{Na}$ tej osnovi se razvijajo tudi nova orodja za ocenjevanje kakovosti osvetlitve (Johansson idr., 2013). Diskusija in raziskave o tem, katere informacije nam lahko nudijo slikovni prikazi predmetov oziroma okolja v primerjavi z resničnim okoljem, so že več let pomembna tema $\mathrm{v}$ psihologiji zaznavanja. James Gibson (1971) postavi teorijo, ki loči slikovno posredovano in neposredno zaznavanje okolja, kljub temu pa poudarja, da dajejo skupno informacijo značilnosti, ki so pri obeh enake. Tudi John M. Kennedy (1974) povzame, da je svetloba »in- formativna « in predstavi različne teorije o tem, kako slike prinašajo informacije opazovalcu. Poudari, da je za razumevanje zaznave predmetov prek slik potrebno ozadje filozofije, fizike in psihologije. Slike so lahko uporabno raziskovalno orodje, zavedati pa se moramo tudi njihovih omejitev.

\section{Raziskovalna metoda}

Za pridobitev informacij o zaznavnem, spoznavnem in čustvenem vplivu nočnega osvetljenega prostora na posameznike smo izoblikovali spletno anketo. Tak način elektronske javne participacije $\mathrm{v}$ povezavi z orodji spleta 2.0 omogoča lažje udeleževanje javnosti v postopkih načrtovanja (glej na primer Bizjak, 2012). V anketi smo uporabili slikovne prikaze prihodnjih osvetlitev na izbranih lokacijah v Ljubljani. Za spremenljivki, označeni z dimenzijama vzbujanja in valentnosti, smo po Russllovem modelu podobno kot Daria Casciani in Maurizio Rossi (2012) izbrali »prijetnost « kot občutek, ki ga občutijo anketiranci ob opazovanju predlogov osvetlitve in » pritegnitev pozornosti« oziroma zanimanje anketirancev za dano osvetlitev. Ti spremenljivki določata afektivno kakovost slik predlaganih osvetlitev in tako vplivata na temeljna čustvena stanja anketirancev. Z vprašanji v spletni anketi smo

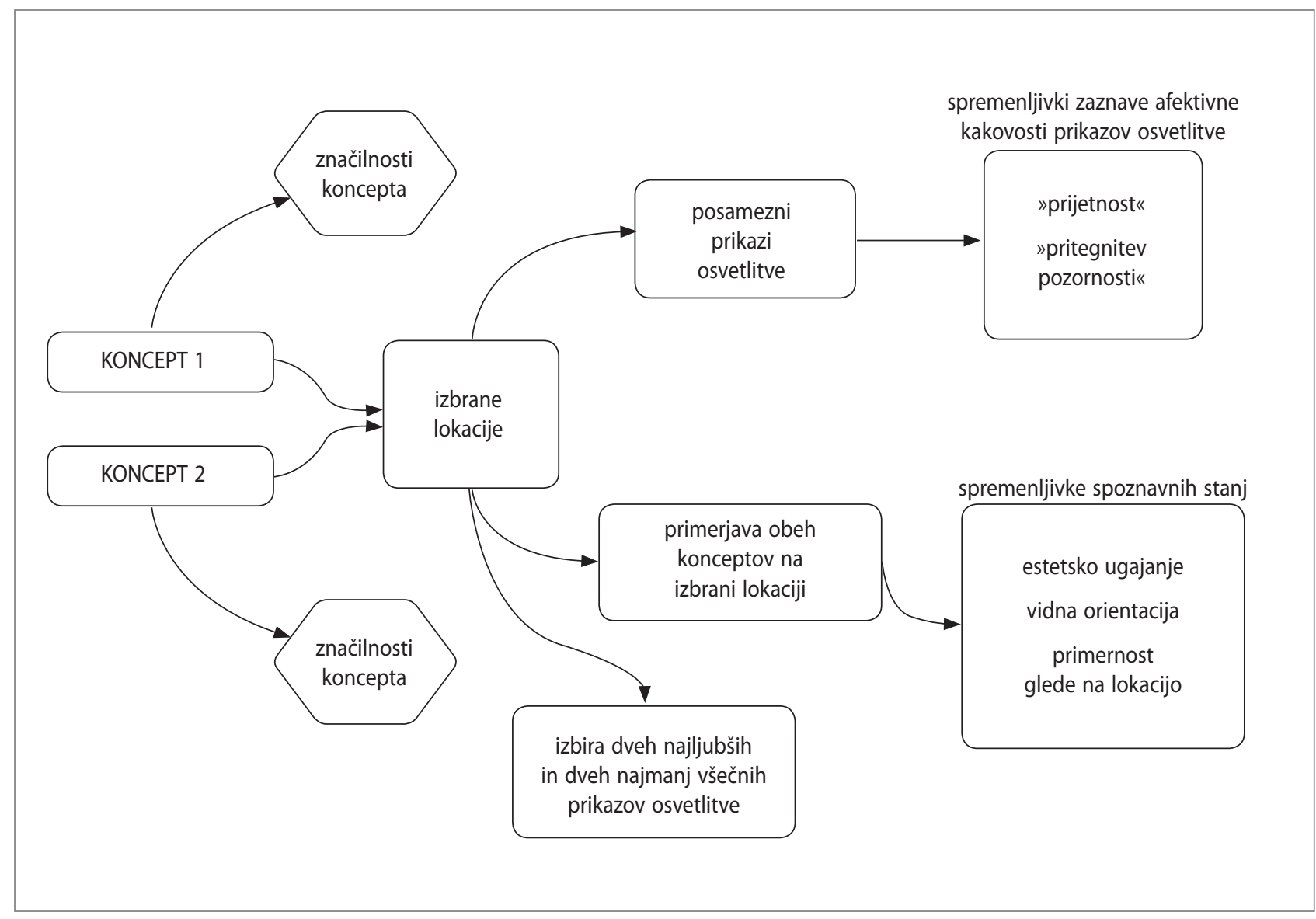

Slika 1: Predstavitev raziskovalnega modela v spletni anketi (ilustracija: Simon Rankel) 
merili stopnjo strinjanja oziroma nestrinjanja anketiranih o »prijetnosti in $»$ pritegnitvi pozornosti predlogov osvetlitve. Spremenljivko pritegnitev pozornosti smo krajše poimenovali kar » pozornost «. Z dvodimenzionalnim modelom čustvenih stanj in s tema indikatorjema smo sestavili spremenljivko, ki označuje raven vpliva oziroma človekovo doživljanje osvetljenega urbanega prostora. Posamezni predlogi prihodnje osvetlitve na različnih lokacijah pomenijo glavne napovedne spremenljivke v raziskavi. $\mathrm{V}$ drugem delu spletne ankete smo predlagana koncepta primerjali neposredno na isti lokaciji mesta. Tu opredelimo spremenljivke, ki temeljijo na psihologiji spoznavnih procesov. Z njimi proučujemo mnenja anketiranih o estetskem ugajanju predlagane osvetlitve, o preglednosti oziroma vidni orientaciji v prikazanem prostoru in primernosti osvetlitvenih predlogov glede na izbrano lokacijo (slika 1). Za mnenja o primernosti predlogov osvetlitve ni nujno, da se ujemajo z estetsko oceno. Spremenljivka vidna orientacija v osvetljenem prostoru pomeni zmožnost spoznavanja urbanih segmentov in njihove preglednosti (Schmidt in Töllner, 2006) in je povezana s pojmom berljivosti prostora (ang. legibility), kot ga definira Lynch (2010). K orientaciji spada tudi zmožnost zaznave hišnih številk in imen ulic. Do neke mere jo lahko povežemo tudi s kriterijem vidne dostopnosti prostora. Ta je definirana kot učinkovitost, $s$ katero lahko uporabljamo vid za varno premikanje po prostoru (Legge idr., 2010). Anketirane smo prosili, naj navedejo tudi dva njim najljubša prizora osvetljenega urbanega okolja in tista, ki sta jim bila najmanj všeč. $S$ tem smo želeli preveriti, ali je lokacija pri anketiranih odločilni dejavnik za izbiro najljubšega prizora, kar posledično vpliva tudi na mnenje o prijetnosti in privlačnosti osvetlitve. To vprašanje smo namenoma postavili na koncu ankete.

\subsection{Zbiranje podatkov in vzorec v raziskavi}

Podatke smo zbirali s strukturiranim spletnim vprašalnikom. Petstopenjsko lestvico, ki smo jo uporabili za ocenjevanje trditev v prvem delu raziskave, smo obravnavali kot intervalno. To smo omogočili z možnostjo podajanja ocene od 1 do 5 , ki označuje stopnjo strinjanja z navedeno trditvijo ( 1 - sploh se ne strinjam, 2 -ne strinjam se, 3 - sem neodločen/a, 4 - se strinjam, 5 - popolnoma se strinjam). Pri vprašanjih ob neposredni primerjavi dveh konceptov so imeli anketirani na izbiro le tri možnosti: odločitev za enega od dveh predlaganih konceptov ali odgovor, da med konceptoma glede obravnavane spremenljivke ni razlik. Anketiranje po spletu je potekalo v oktobru 2012 in je trajalo tri tedne. Spletni vprašalnik je bil dostopen na spletni povezavi, ki smo jo po elektronski pošti poslali različnim skupinam ljudi. Povezavo smo posredovali tudi različnim skupinam družabnega omrežja Facebook in 550 slovenskim arhitektom oziroma izbranim oblikovalcem osvetlitve.

\subsection{Izbira lokacij in njihove značilnosti}

Izbrali smo pet lokacij znotraj ljubljanskega avtocestnega obroča. Zajemajo tipične mestne elemente, kot so ceste in pešpoti, stavbe, mostovi, trgi, ploščadi, parkirišča, parki in krajinski elementi. Izbrana območja se razlikujejo po namembnosti prostora. Ta se lahko pri določenem območju prekriva. Prve tri lokacije so območje Gosposvetske ceste, Ajdovščina in Park slovenske reformacije. Namenske rabe območja so stanovanjska, upravna, storitvena, izobraževalna in kulturna. Te tri lokacije so na pomembnem prehodu iz poslovnega središča mesta na prometna in trgovsko-storitvena območja. Del obravnavanega območja je po predpisih s področja varstva kulturne dedišcine (Prosenc in Potočnik, 2011) varovan kot spomeniško območje. Četrta lokacija je Trnovski pristan ob Ljubljanici. V obravnavo je vključen tudi Hradeckega most, ki se navezuje na Grudnovo nabrežje na Prulah. To je območje stanovanj in storitvenih dejavnosti ter hkrati vhod v osrednji turistični del središča Ljubljane. Obrežje Ljubljanice v Trnovskem pristanu vse do Špice je pomembno mestno sprehajališče in kot povezovalna struktura temeljni element razpoznavne strukture mesta (Sašek Divjak, 2008). Na nabrežju se ob poletnih večerih zbira mladina. Peta lokacija prikazuje tipski blok in pešpoti v Savskem naselju. To je stanovanjska soseska s številnimi stanovanjskimi bloki, stolpnicami, parkirišči in garažami, ki se nahaja blizu osrednjega dela mesta, zraven Kliničnega centra in železniške postaje. Pri vsaki lokaciij smo izbrali pogled, ki jo čim bolje določa. Na splošno je pri zunanji osvetlitvi Ljubljane moteče bleščanje svetil in uhajanje svetlobe. Oglasni panoji sredi mesta so presvetli, nočna podoba glavnih ulic ni urejena, prostori ob stičiččih glavnih prometnic pa so preosvetljeni. Prehodi za pešce so ponekod slabo osvetljeni, nekonsistentna pa je raba korelirane temperature barve (ang. correlated color temperature) virov svetlobe. Razsvetljava za prometne znake je potratna, možnosti regulacije svetil v glavnem ni. Analiza stanja osvetlitve izbranih lokacij kaže, da kljub nekaterim novejšim izboljšavam, ki so posledica zahtev uredbe o omejevanju svetlobnega onesnaževanja, z veliko vidikov sedanja osvetlitev še vedno ni ustrezna. Pri večini obravnavanih lokacij nočna podoba mesta ni upoštevana. Določeni poskusi, ki težijo k temu, so zelo stihijski. Trnovski pristan je mestni predel, na katerega so meščani zelo navezani. Tu bi z izboljšano, toda diskretno osvetlitvijo še dodatno pripomogli $k$ izboljšanju podobe tega dela mesta. V primeru Ajdovšcine in Gosposvetske ceste poskušamo $\mathrm{z}$ osvetlitvijo prispevati tudi $\mathrm{k}$ povrnitvi pomena teh dveh delov mesta, ki sta »imela v preteklosti bistveno bolj specifičen značaj kot danes « (Bandur, 2012). V stanovanjskih soseskah oziroma blokovskih naseljih Ljubljane bi z izboljšano osvetlitvijo pripomogli tudi $\mathrm{k}$ prijetnejšemu počutju ljudi. Z njo bi lahko revitalizirali starejše in manj privlačne okoliše. Poudarek mora biti na čutni in diskretni osvetlitvi, ki bi delovala, 
le ko je treba. Stanovalcem bi tako omogočala nočni počitek in hkrati nudila prijeten pogled na stanovanjski mestni prostor.

\subsection{Prihodnja koncepta osvetlitve in prikazi}

Na podlagi dnevnih fotografij današnjega stanja smo izoblikovali po dva prihodnja predloga osvetlitve za vsako od petih izbranih lokacij. Fotografije so bile narejene v pomladnem in poletnem času, ko ni bilo padavin. Izoblikovana koncepta osvetlitve se namenoma očitno razlikujeta. Oba upoštevata določene kriterije urbanističnega oblikovanja. $V$ obeh primerih so upoštevane vidne zahteve funkcionalne osvetlitve prometnih cest in pešpoti. Pri obeh je poudarek na porazdelitvi svetlobe in zmanjšanju njenega neželenega uhajanja, zmanjšanju bleščanja in ojačenju vidnih vedut. Prvi koncept smo poimenovali ploskovni koncept, drugega pa detajlni koncept. Pri prvem je poudarjena enakomerna ploskovna osvetljenost prostora, kot tudi večje nežno svetleče površine. Gre za namestitev svetil na pročelja hiš, stene objektov in $\mathrm{v}$ tla. Ta svetila imajo ponekod poleg ambientalnega hkrati tudi funkcionalni pomen. Svetle kolesarske steze in prehodi za pešce so pomembni tudi zaradi varnosti in informativne orientacije. Osvetlitev se izogiba prevelikim kontrastom na tleh, kar bi lahko motilo predvsem starejše prebivalce in obiskovalce. Pri detajlnem konceptu so poudarjeni prepletenost svetlobe in teme, ustvarjanje urbanega ritma in razkrivanje primernih svetlobnih kontrastov. Skritih arhitekturnih elementov, ki jih ponoči ne želimo prikazati, ne osvetlimo. Poudariti želimo razpoznavanje razlik v grajeni mestni strukturi in izbrane detajle, kot tudi vzpostaviti izgubljene povezave. Poudarek je na uporabi svetil LED in OLED $\mathrm{v}$ arhitekturnih elementih, kot so okna in robovi. Informacijske table in oznake so jasne in dobro vidne. Ta koncept je v splošnem manj svetel kot ploskovni. Arhitekturni elementi oziroma grajena urbana struktura pri obeh konceptih v osnovi ostaja taka, kakršna je. Predvidimo lahko le manjše spremembe urbane opreme. Reklamni panoji in izložbe so pri obeh konceptih osvetlitve osvetljeni diskretno. Tako ne prevladujejo in omogočajo, da so dobro vidni tudi znaki, kažipoti in table z različnimi informacijami. Njihova osvetlitev ne želi »tekmovati $\mathrm{z}$ ambientalno urbano osvetlitvijo. Lokali in restavracije so pri obeh konceptih osvetljeni diskretno. Tanke prosojne plasti svetil OLED na pročeljih izbranih zgradb ne bi spremenile dnevne podobe mesta. Njihova umestitev bi morala biti v skladu z uravnoteženo strategijo urbane prenove (Ho idr., 2012). Ta svetila bi bila lahko združena s hibridnimi svetlobnimi sistemi (glej na primer Mayhoub in Carter, 2012), ki za osvetlitev notranjosti stavb sočasno uporabljajo dnevno svetlobo in umetne vire svetlobe. Nekatere stavbe na obravnavanih območjih spadajo med spomenike naravne in kulturne dediščine. To velja za pročelja hiš na Gosposvetski cesti, določene elemente Parka slovenske reformacije in nekaj stavb na območju Ajdovščine (Ur. l. RS, št. 60/1993). Po zakonu moramo varovati strnjeno ulično pročelje Gosposvetske ceste. Zakon o varstvu kulturne dediščine (Ur. l. RS, št. 16/2008) določa, da ne smemo posegati v arhitekturno strukturo oziroma uničevati pročelij. Za tako postavitev prosojnih OLED-svetil bi morali najprej pridobiti kulturnovarstveno soglasje. Svetila OLED bi lahko namestili tudi na okna izbranih stavb. Taka okna bi podnevi ohranila svojo funkcijo, ponoči pa bi imela za stanovalce funkcijo navojnic. Na zunanji strani bi nežno svetila. Če bi ponoči tako okno odprli, bi se svetlobna navojnica nežno ugasnila. Določena LED- in OLED-svetila bi lahko, predvsem za nestalne dekorativne namene, svetila tudi v izbrani enobarvni svetlobi. Carl Gardner (2006) opozarja, da lahko pride pri uporabi barv v zunanjem prostoru hitro do napačne uporabe. Prav tako so pomembna tudi dognanja dosedanjih raziskav o vplivu barv na človekovo obnašanje in zaznavanje okolja (glej Ab. Jalil idr., 2012). Pri stalni zunanji razsvetljavi je pomembna uporaba ustrezne korelirane temperature barve virov bele svetlobe in njihova spektralna porazdelitev. Pri nekaterih LED- in OLED-svetilih lahko temperaturo barve ustrezno prilagajamo, pri čemer poznamo več metod nadzora (Kim idr., 2012). Prosojna svetila OLED bi uporabili tudi za poudarjanje cestnih označb, kot so prehodi za pešce, kolesarske steze ali robovi pločnikov. Tako umestitev bi bilo treba dobro pretehtati s stališč prometne varnosti in vidnega zaznavanja. Svetila OLED ali LED bi bilo po našem mnenju smiselno uporabiti za prikaz hišnih številk in imen ulic, saj so ti detajli v nočnem času slabo vidni. V prikazih je veliko podrobnosti. Pri detajlnem konceptu so taki napisi ulic na pročeljih hiš, svetleče hišne številke in številni osvetljeni manjši arhitekturni detajli. Omenjene rešitve smo vnesli v slikovne prikaze. Na primeru ploskovnega koncepta Gosposvetske ceste (GK1) smo poskušali ustvariti kontinuiteto večjih vertikalnih površin bližnjih stavb (slika 2a). Z nežno sijočimi pročelji hiš, diskretno svetlečo kolesarsko stezo in ločilno dvojno črto na cesti omogočimo, da opazovalec zaznava kompleksno fizično značilnost urbanega prostora kot povezano celoto. Deli pročelij hiš so poudarjeni, svetlost pročelja pa se gradientno zmanjšuje od višine proti tlom. Taka osvetlitev bi bila vključena le ob določenih večernih urah. Takrat ko v mestu skoraj ni prometa in sprehajalcev, pa bi bila popolnoma izključena.

Diskretna OLED-svetila na kolesarski stezi pešcem in voznikom kažejo, da je ta del pločnika namenjen kolesarjem in da morajo biti pri njegovem prečkanju še posebej previdni. Svetlost te površine je le tolikšna, da oko zazna razliko glede na druge dele pločnika oziroma ceste. Pri detajlnem konceptu (GK2) smo kontinuiteto pogleda poskušali ustvariti s ponavljanjem ritmičnega presledka oken OLED in svetlim robom pločnika (slika 2b). Svetleča okna na stavbi Metalke zaznamujejo vidni okvir. Svetleči robovi pločnikov so hkrati ločnice in 

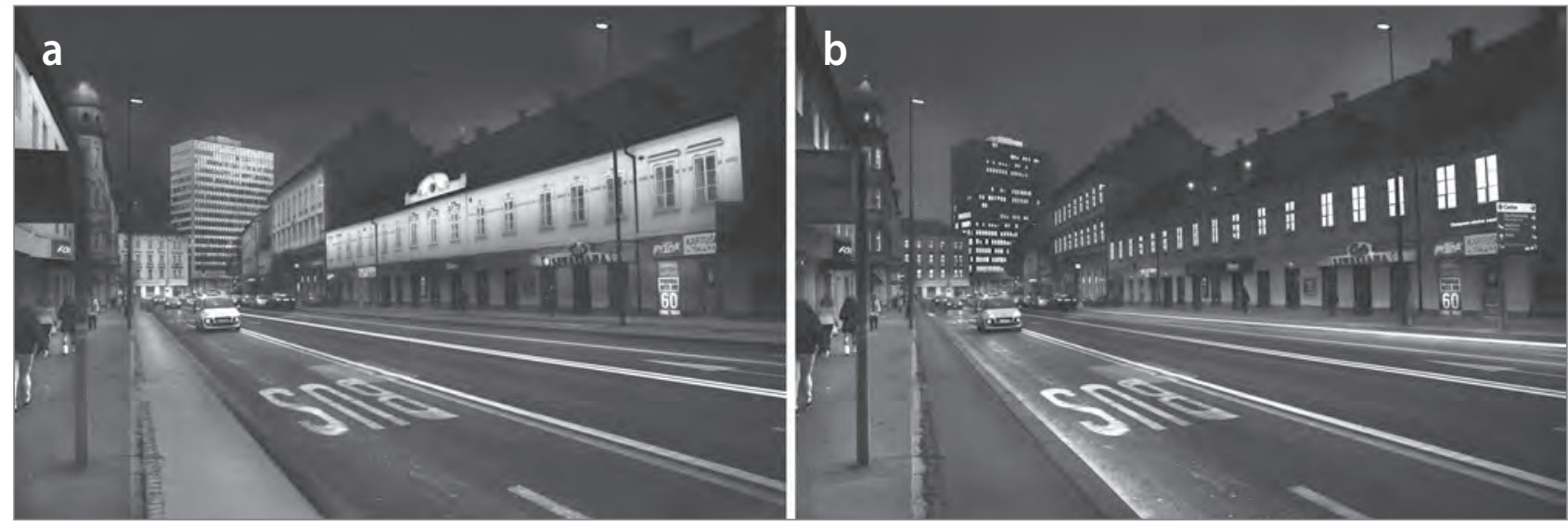

Slika 2: (a) Gosposvetska cesta, ploskovni koncept GK1, (b) Gosposvetska cesta, detajlni koncept GK2 (foto in oblikovanje: Simon Rankel)



Slika 3: (a) Ajdovščina, ploskovni koncept AK1, (b) Ajdovščina, detajlni koncept AK2 (foto in oblikovanje: Simon Rankel)

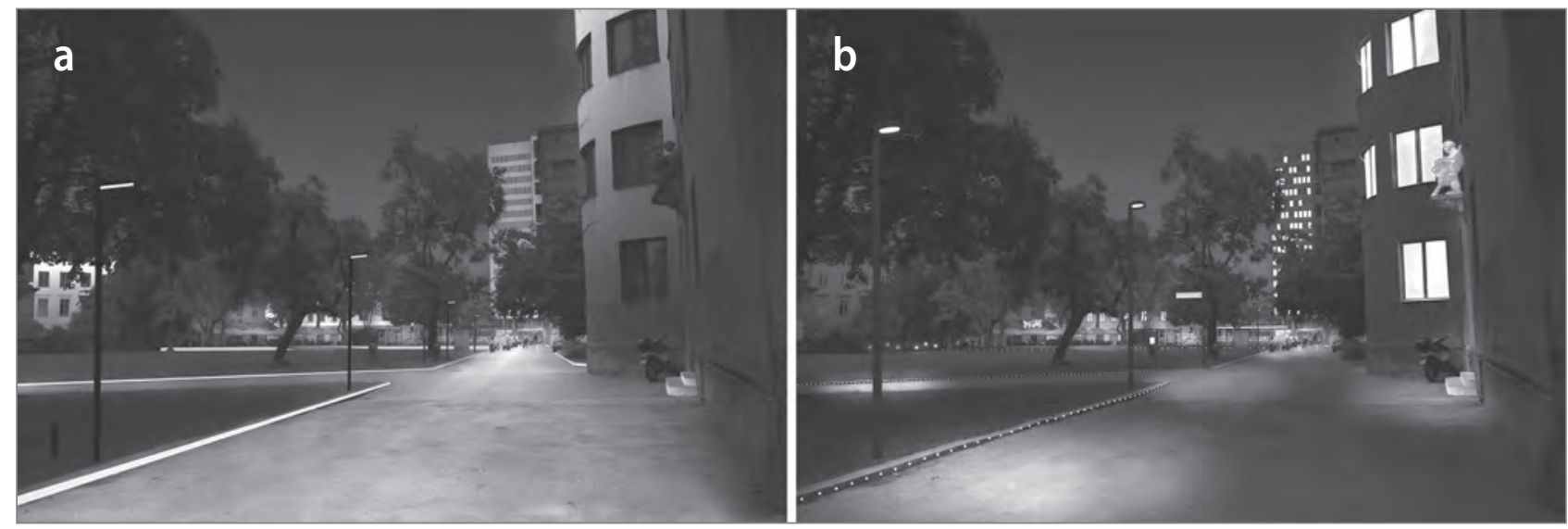

Slika 4: (a) Park slovenske reformacije, ploskovni koncept PK1, (b) Park slovenske reformacije, detajlni koncept PK2 (foto in oblikovanje: Simon Rankel)

povezovalni elementi celote. Osvetlitev izložb je zmanjšana na minimalno raven. Pozornost je namenjena osvetlitvi informacijskih znakov in tabel, ki omogočajo boljši pregled in orientacijo za pešce in voznike. Prav tako nežno svetijo hišne številke in imena ulic. Določeni arhitekturni detajli so blago osvetljeni.

Vidni okvir vidnega območja smo pri ploskovnem konceptu Ajdovšcine (AK1) poudarili z nežno svetlimi izbranimi OLED-pročelji stavb (slika 3a). Osvetljeno pročelje Metalke je bolj poudarjeno kot druga. Z večjimi svetlimi površinami smo poskušali osmisliti današnjo precej kaotično nočno podobo na Ajdovšcini. Nekatere površine diskretno svetijo tudi v barvah, kar ustvari večjo stopnjo zanimanja. Velikim presvetlim oglasnim tablam se zmanjša svetlost, ki se prilagaja tudi vremenskim razmeram. Svetleča pročelja se pozno ponoči izklopijo. Vključene ostanejo le redke manjše svetle površine. Pri detajlnem konceptu Ajdovščne (AK2) gradimo vidni okvir s pomočjo oken OLED in arhitekturnih detajlov (slika 3b). Po- 



Slika 5: (a) Trnovski pristan, ploskovni koncept TK1, (b) Trnovski pristan, detajlni koncept TK2 (foto in oblikovanje: Simon Rankel)


Slika 6: (a) Savsko naselje - tipski blok, ploskovni koncept SK1, (b) Savsko naselje - tipski blok, detajlni koncept SK2 (foto in oblikovanje: Simon Rankel)

udarimo tudi podhod, imena ulic, napise in prometne znake. Osvetlitev temelji na diskretni osvetlitvi ter menjavanju svetlih in temnih površin. Določeni arhitekturni elementi na trgu se osvetlijo le po potrebi, ob posebnih večernih dogodkih ali prireditvah. Prehodi za pešce so poudarjeni z vgrajenimi svetili OLED, ki bi zasvetila le ob rdeči luči na semaforju za voznike. Pri obeh konceptih osvetlitve Ajdovščine in Gosposvetske ceste so lokali in izložbe slabše osvetljeni, da smo lahko med konceptoma bolj poudarili razlike $\mathrm{v}$ arhitekturni osvetlitvi.

Pri ploskovnem konceptu osvetlitve Parka slovenske reformacije (PK1) je v ospredju enakomerna osvetlitev pešpoti (slika 4a).Vidni okvir tvorijo izbrana svetla pročelja, ki poudarjajo tudi jasnost in preprostost oblik parka. Taka OLED-svetila so nameščena le na določenih stavbah. Njihova svetlost se nežno zmanjšuje v smeri proti tlom. Poudarjeni robovi pripomorejo $\mathrm{k}$ občutku orientacije. Diskretno poudarimo majhna stopnišča pred vhodi v stanovanjske bloke. Svetilom, ki osvetljujejo pešpoti v parku, se v poznem nočnem času zmanjša svetilnost. Pri njih lahko prilagajamo temperaturo bele barve svetlobe. Koncept temelji na čistosti in jasnosti. Pri detajlnem konceptu (PK2) je poudarek na prepletanju temnih in svetlih površin (slika 4b). Okolica je tu manj osvetljena. Pešpoti so osve- tljene neenakomerno. Robovi pločnikov so točkasto osvetljeni. Na stavbah osvetlimo arhitekturne elemente, kot so kamnite figure nad vhodi v stavbe. Osvetlimo tudi table imen ulic in parka. Poudarjeni so napisi gostinskih dejavnosti. Zmožnost orientacije $\mathrm{v}$ parku poskušamo okrepiti s svetlobno poudarjenimi večjimi objekti zunaj parka. Berljivost prostora se ustvari z jasno poudarjenimi vhodi v stanovanjske objekte, ki jih lahko med seboj ločimo, na primer z izbiro barv stopnic pred vrati.

Pri ploskovnem konceptu za Trnovski pristan (TK1) predlagamo umestitev linijskih OLED-svetil, ki poudarijo jasnost kamnitih elementov nabrežja (slika 5a). Veččrtna razsvetljava omogoča zaznavanje nabrežja kot povezane celote. Hradeckega most $\mathrm{v}$ daljavi ima dominantno osvetljen vertikalni nabrežni del, ki prehaja $\mathrm{v}$ dobro vidne in $\mathrm{v}$ celoti osvetljene značilne stebre mostu. Del mostu nad Ljubljanico pa je osvetljen diskretneje in deluje lahkotneje. Linijska osvetlitev skupaj z osvetlitvijo mostu tvori vidni okvir, ki ustvari značilno nočno podobo tega predela. Pri detajlnem konceptu (TK2) linijski poudarek prestavimo na most (slika $5 \mathrm{~b}$ ). Tu poudarimo le njegov spodnji lok. Zgodovinski pomen mostu poudarimo z nežno svetlimi napisi njegovega imena. Ohranimo značilne luči na stebrih mostu. Stopnišče kot del nabrežja osvetlimo s točkastimi svetili 
LED, ki svetijo proti tlom. Jakost svetlobnega toka točkastih svetil se prilagaja vremenskim razmeram in osvetljenosti okolice in je ves čas na ustrezno nizki ravni. Svetle točke delujejo kot zanimiv svetleč element, ki ne razvrednoti tega namenoma temnejšega dela mesta.

Pri ploskovnem konceptu osvetlitve tipskega bloka v Savskem naselju (SK1) z OLED-svetili, nameščenimi na spodnji del pročelja stanovanjskega bloka, nadomestimo svetila za osvetljevanje poti ob bloku (slika 6a). Glavna svetila OLED na nadstreških vhodov se vključijo le ob navzočnosti bližajoče se osebe in poudarijo pomen vhoda. Vidno se ujemajo s svetlečimi elementi vertikalnih površin na balkonskih ograjah. Ključavnice in kljuke glavnih vhodnih vrat so nežno osvetljene, kar olajša odpiranje vrat. Robnik pločnika z umeščenimi linijskimi svetili OLED poudarja smer glavne poti in izboljšuje občutek orientacije v prostoru. Ta svetila se izključijo po določeni uri, ko je v naselju le malo obiskovalcev, ali pozimi, ko jih prekrije sneg. Pomembnejša stičiššca poti in stopnišča nežno osvetlimo. To poveča subjektivni občutek varnosti in omogoči vidnost pomembnejših točk v daljavi. Pri detajlnem konceptu osvetlitve tipskega bloka (SK2) so poudarjeni le vhodi stanovanjskega bloka (slika 6b). Taka osvetlitev je energetsko manj potratna. Temelji na poudarkih ter menjavanju temnih in svetlih površin. Vhode poudarimo z linijskimi svetili OLED, umeščenimi na robove nadstreškov. Nežno svetle oznake hišnih številk in imena ulic prestavimo na vidnejša mesta stanovanjskega bloka. Redki prometni znaki zasvetijo le po potrebi (ko v daljavi zaznajo luči bližajočega se vozila). Poti osvetlimo neenakomerno z uličnimi svetili LED. Kljub taki osvetlitvi pot iz večje opazovalne razdalje deluje kot povezana celota. Slovenska uredba o mejnih vrednostih svetlobnega onesnaževanja (Ur. l. RS, št. 81/2007) določa, da mora upravljavec razsvetljave pročelja zagotoviti, da svetlost osvetljenega dela pročelja, izračunana kot povprečna vrednost celotne površine osvetljenega dela pročelja, ne presega $1 \mathrm{~cd} / \mathrm{m}^{2}$. V raziskavi predvidevamo, da bi bile prihodnje tankoslojne plasti OLED obravnavane kot drugačna kategorija razsvetljave. Tu ne bi šlo za osvetljena pročelja, temveč za svetleča, ki pa jih ne bi šteli v kategorijo reklamnih panojev. Take kategorije svetil sedanja uredba ne obravnava. Opisana razsvetljava ne bi svetila vso noč, temveč le v večernih urah in izbrani lokaciji primerno. Čas delovanja bi se prilagajal letne-

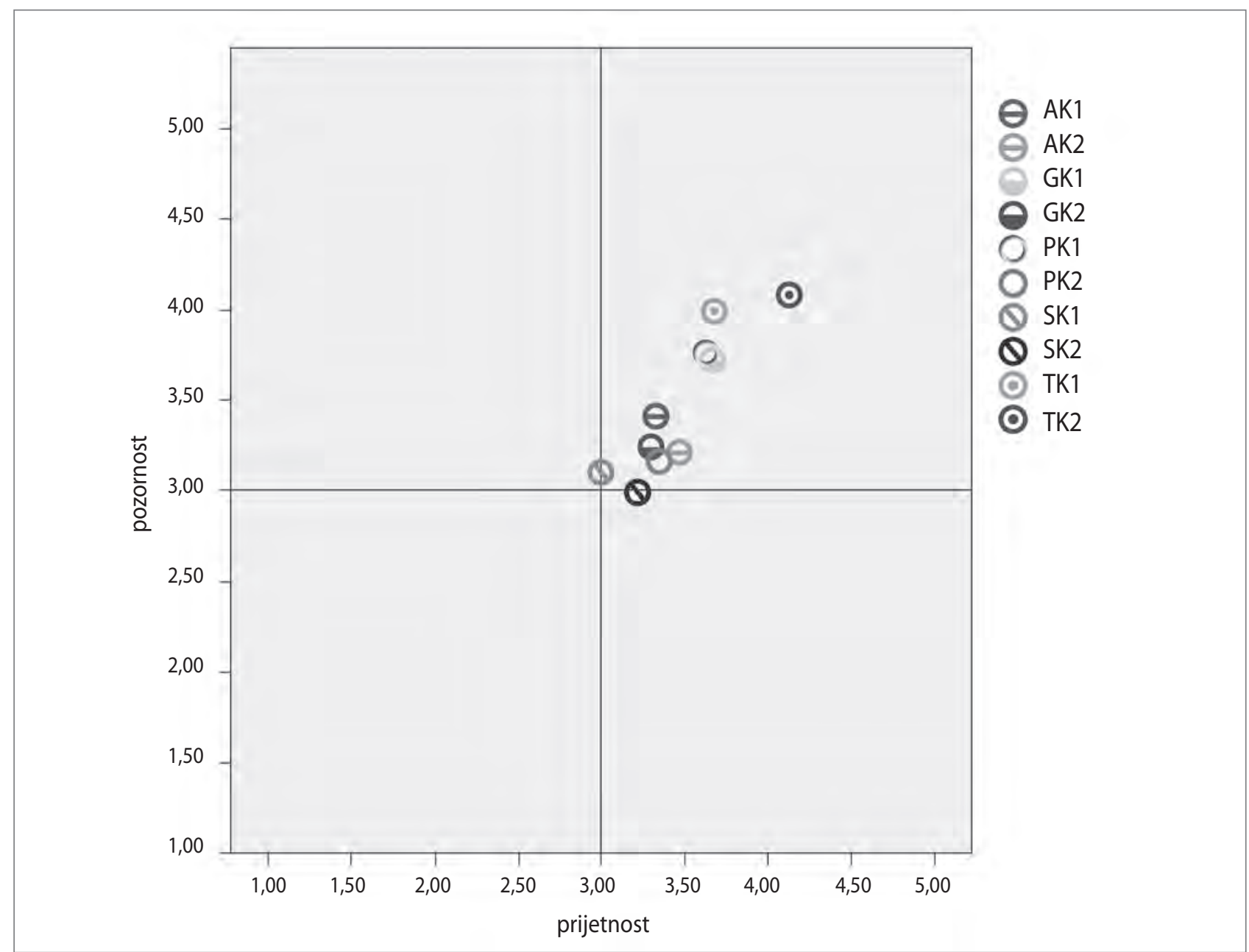

Slika 7: Prikaz povprečnih vrednosti spremenljivk »prijetnost« in »pozornost« na dvodimenzionalnem grafu za posamezne koncepte in lokacije (ilustracija: Simon Rankel) 
mu času ter gostoti prometa in pešcev, svetlost pa vremenskih razmeram in okoliški osvetljenosti. Sevanje nad vodoravnico bi bilo onemogočeno z uporabo napredne tankoslojne optike. Poleg ambientalne vloge bi svetila OLED na pročeljih ob primerni postavitvi lahko imela tudi vlogo osvetljevanja bližnjih talnih površin. Poleg njihove svetlosti bi nadzirali tudi delež svetlobnega toka, ki s takih pročelij doseže tla. To bi pomenilo novo hibridno kategorijo razsvetljave.

\section{Rezultati}

Raziskava je bila izvedena $\mathrm{v}$ slovenskem jeziku med anketiranimi, ki so v večini doma v Sloveniji. Domnevamo tudi, da je večina anketiranih poznala lokacije predlogov. Prikazi konceptov v anketi so bili barvni. $\mathrm{V}$ vzorec raziskave je bilo vključeno 528 anketiranih oseb. Delež žensk je bil nekoliko večji (53,2 \%) kot delež moških (46,8 \%). Po pregledu opisnih statistik in frekvenčnih porazdelitev ocen predlogov smo strnjene rezultate povprečnih vrednosti ocen spremenljivk $\gg$ prijetnosti « in »pozornosti « prikazali na dvodimenzionalnem grafu. Ločilni črti delita prikaz na štiri kvadrante. Črti prikazujeta vrednost 3, ki pomeni neodločenost o oceni spremenljivke. Levi spodnji kvadrant prikazuje vrednosti nestrinjanja $s$ trditvami o $\gg$ prijetnosti $\ll$ in $\gg$ pozornosti $\ll$. Desni zgornji kvadrant prikazuje vrednosti strinjanja s trditvami o »prijetnosti in »pozornosti . Druga kvadranta prikazujeta ocene strinjanja le z eno od obeh spremenljivk.

Rezultati kažejo, da je večina povprečij ocen osvetlitvenih predlogov v zgornjem desnem kvadrantu (slika 7). To lahko razumemo kot nagnjenost $\mathrm{k}$ strinjanju s trditvami o » prijetnosti « in » pozornosti «. Le povprečne vrednosti ocen na lokaciji Savskega naselja so blizu ločitvenih črt kvadrantov. To pomeni $\mathrm{v}$ povprečju neodločenost o oceni posamezne spremenljivke. Rezultate za posamezni spremenljivki smo prikazali s tako imenovanimi kvartilnimi diagrami (ang. box plot). Škatlast okvir diagrama prikazuje, kje je ocena $50 \%$ odgovorov. Odebeljena črta je središčnica. $S$ krogci so označene izstopajoče vrednosti (ang. outliers).

Z diagrama spremenljivke » prijetnost « (slika 8a) je razvidno, da se anketiranci strinjajo, da je prijetna večina predlogov osvetlitve. Izstopata predloga za Trnovski pristan, pri katerih so ocene višje kot pri preostalih predlogih, ter predloga osvetlitve bloka v Savskem naselju, za katera anketiranci menijo, da sta manj prijetna. Pri prikazu spremenljivke »pozornost « (slika 8b) je nagnjenost k strinjanju opazna le pri Trnovskem pristanu ter pri ploskovnih konceptih Gosposvetske ceste in Parka slovenske reformacije. Kombinacija rezultatov obeh diagramov potrjuje težnjo $\mathrm{k}$ strinjanju z vsaj eno od omenjenih spremenljivk pri vseh lokacijah in konceptih, razen pri bloku v Savskem naselju, pri katerem je polovica vrednosti ocen pri obeh spremenljivkah med 2 in 4 . Izstopata predloga pri Trnovskem pristanu, pri katerih je pri ploskovnem konceptu polovica vrednosti ocen med 3 in 5, pri detajlnem konceptu pa celo med 4 in 5 za obe spremenljivki. Pri ploskovnih predlogih osvetlitve Gosposvetske ceste in parka je polovica ocen strinjanja $s$ »prijetnostjo « med 3 in 4, polovica ocen »pozornosti «, ki bi jo pritegnila omenjena koncepta, pa med 3 in 5. Polovica anketiranih je ploskovni koncept osvetlitve Ajdovščine glede obeh spremenljivk ocenila med 3 in 4. Predloga detajlnih osvetlitev Ajdovšcine in Gosposvetske ceste sta glede spremenljivke »pozornost « $\mathrm{v}$ večini ocenjena med 2 in 4, glede spremenljivke »prijetnost « pa med 3 in 4. Ocene predlogov osvetlitve, razen za blok v Savskem naselju, potrjujejo, da se anketirani $\mathrm{v}$ glavnem strinjajo $s$ trditvami o »prijetnosti in $\gg$ pozornosti . Koncepta osvetlitve bloka v
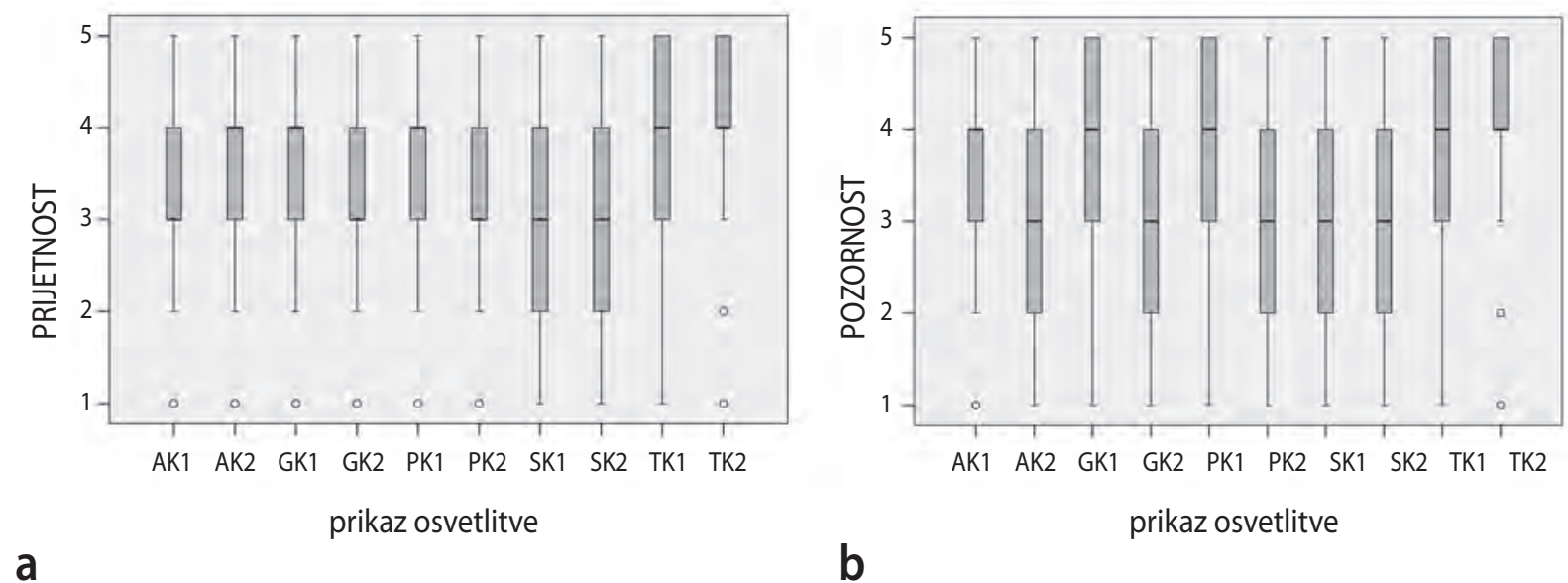

Slika 8: (a) Prikaz ocen spremenljivke »prijetnost« s kvartilnimi diagrami, (b) prikaz ocen spremenljivke »pozornost« s kvartilnimi diagrami (ilustracija: Simon Rankel) 
Preglednica 1: Primerjava povprečnih ocen »prijetnosti« in »pozornosti« med konceptoma

\begin{tabular}{lllll}
\hline spremenljivka & lokacija & statistična značilnost & povprečje 1 & povprečje 2 \\
\hline prijetnost & Gosposvetska cesta & 0,000 & 3,67 (GK1) & 3,31 (GK2) \\
\hline pozornost & Gosposvetska cesta & 0,000 & 3,73 (GK1) & 3,24 (GK2) \\
\hline prijetnost & Ajdovščina & 0,010 & 3,33 (AK1) & 3,47 (AK2) \\
\hline pozornost & Ajdovščina & 0,001 & 3,41 (AK1) & $3,21($ AK2) \\
\hline prijetnost & Park reformacije & 0,000 & $3,63($ PK1) & 3,35 (PK2) \\
\hline pozornost & Park reformacije & 0,000 & 3,76 (PK1) & $3,16($ PK2) \\
\hline prijetnost & Trnovski pristan & 0,000 & $3,68($ TK1) & 4,13 (TK2) \\
\hline prijetnost & Savsko naselje & 0,000 & $3,00($ SK1) & 3,22 (SK2) \\
\hline
\end{tabular}

Savskem naselju se anketiranim na splošno nista zdela posebej prijetna niti privlačna, čeprav je prav pri njiju kar nekaj dobrih rešitev osvetlitve. Te ocene smo primerjali še z izbiro najljubših in najmanj priljubljenih prizorov. Primerjavo povprečnih ocen » prijetnosti « in »pozornosti « med ploskovnim in detajlnim konceptom smo izvedli s tako imenovanim statističnim testom dvojic oziroma $t$-testom. $Z$ njim ugotavljamo, ali so razlike $\mathrm{v}$ povprečjih vrednosti ocen posamezne spremenljivke med konceptoma na posamezni lokaciji statistično pomembne. Ker so pri večini predlogov ocene obeh spremenljivk porazdeljene precej normalno, smemo uporabiti omenjeni parametrični test. Rezultati kažejo, da so razlike povprečij ocen posameznih predlogov osvetlitve dovolj velike in značilne s 95-odstotno verjetnostjo (torej je za naključnost rezultatov manj kot 5-odstotna verjetnost) pri večini predlogov (preglednica 1).

$T$-statistika ni bila 95-odstotno značilna le pri spremenljivki »pozornost« pri Trnovskem pristanu (statistična značilnost: 0,176; povprečji: TK1 $=4,00$; TK2 $=4,07)$ in pri spremenljivki » pozornost« pri Savskem naselju (statistična značilnost: 0,077; povprečji: SK1 = 3,11; SK2 = 2,99). Pri teh dveh primerjavah parov ne moremo s 95 -odstotno verjetnostjo trditi, da se rezultati ocen spremenljivke » pozornost « med konceptoma razlikujejo. V drugem delu ankete smo anketirane spraševali o izbiri preferenčnega koncepta na posamezni lokaciji mesta. Pri tem nas je zanimalo njihovo mnenje glede estetskega ugajanja, občutka vidne orientacije v prikazanem prostoru in primernejše izbire določenega koncepta. Če se jim predloga osvetlitve pri določeni spremenljivki nista zdela dovolj različna, so imeli možnost izbrati tudi odgovor, da med predlaganima konceptoma osvetlitve ni razlik. Pri Gosposvetski cesti, Parku slovenske reformacije in Savskem naselju je večina anketiranih izbrala ploskovni koncept za vse obravnavane spremenljivke (slika 9).

Izbira ploskovnega koncepta je značilna za spremenljivko vidna orientacija za večino lokacij. Le v primeru Trnovskega pristana so glede te spremenljivke rezultati izbir približno enaki. Gle- de estetike izstopajo izbire detajlnega koncepta pri Trnovskem pristanu in Ajdovščini ter izbira ploskovnega koncepta pri Parku slovenske reformacije. Pri Gosposvetski cesti in bloku v Savskem naselju so izbire dokaj enakovredne, z nekoliko večjim deležem pri ploskovnem konceptu. Pri Trnovskem pristanu je večina za bolj estetski koncept izbrala detajlni koncept s točkasto osvetlitvijo nabrežja in nežno osvetljen Hradeckega most. Ta predlog osvetlitve je anketiranim v splošnem zelo ugajal. To so pokazale tudi zelo pozitivne ocene glede »prijetnosti« in »pozornosti« iz prvega dela ankete. Zelo podobne rezultate kot pri estetiki dobimo pri izbiri primernejšega koncepta za dano lokacijo. Pri Gosposvetski cesti in Parku slovenske reformacije prednjači ploskovni koncept, pri Trnovskem pristanu in Ajdovščini pa detajlni. Primerjava rezultatov tega dela ankete s prvim delom pokaže precejšnje ujemanje, predvsem pri Gosposvetski cesti, Parku slovenske reformacije in Trnovskem pristanu. Boljše ocene »prijetnosti《 in »pozornosti« se skladajo $\mathrm{z}$ izbiro koncepta in oceno njegove primernosti na dani lokaciji. Ob koncu ankete smo anketirane povprašali o izbiri dveh najbolj in dveh najmanj všečnih prizorov predlaganih osvetlitev. Za najljubši prizor je skoraj $60 \%$ vseh anketiranih izbralo detajlni koncept pri Trnovskem pristanu. S 17 \% sledi ploskovni koncept pri Trnovskem pristanu. Preostali predlogi so bili izbrani veliko redkeje. Druga najljubša prizora sta osvetlitvi parka. Sledita ploskovna koncepta Trnovskega pristana in Gosposvetske ceste. Za najmanj všečen prizor je večina izbrala detajlni koncept pri Savskem naselju, sledita ploskovni koncept naselja in Ajdovščine. Sklepamo, da lokacija pri anketiranih vpliva na izbiro najljubšega prizora. To posledično vpliva tudi na mnenje o prijetnosti in privlačnosti osvetlitve na posamezni lokaciji.

\section{Razprava}

Študija kaže, da se anketirani v svojih ocenah o afektivni kakovosti slik predlogov prihodnje osvetlitve v povprečju strinjajo $s$ trditvami o občutku » prijetnosti « in pritegnitvi » pozor- 




Slika 9: Prikaz izbir preferenčnega koncepta pri posameznih lokacijah (ilustracija: Simon Rankel)

nosti . To je opazno pri vseh obravnavanih lokacijah hkrati za obe spremenljivki, razen pri ocenah $»$ prijetnosti ploskovne osvetlitve in ocenah »pozornosti $\ll$ detajlne osvetlitve bloka in okolice v Savskem naselju. V teh primerih so bile podane v povprečju neodločene ocene anketiranih. Tu lahko potrdimo vpliv lokacije na izbiro najmanj všečnih prizorov in $s$ tem vpliv na ocene teh predlogov. Tak vpliv zaznamo tudi pri pozitivni oceni obeh osvetlitev pri Trnovskem pristanu. Izkaže se, da je ploskovni koncept anketiranim prijetnejši pri gosteje pozidanih lokacijah v središču mesta, kot je Gosposvetska cesta. Vzrok za tako izbiro so tu najverjetneje večje svetle površine, ki omogoča, da lahko opazovalci precej kompleksen prostor zaznajo kot povezano celoto. Take celote pa ne smejo biti preobsežne niti jih ne sme biti preveč. To opazimo v primeru Ajdovšcine, pri katerem ploskovni koncept večini anketirancev ni preveč všeč. Detajlni koncept je glede prijetnosti bolje ocenjen pri lokacijah, ki niso popolnoma v središču mesta in jim bolj ustreza diskretnejša osvetlitev. $\mathrm{V}$ teh prizorih je več naravnih prvin, kot sta voda in rastje. V članku ugotavljamo, da bi ploskovni koncept pritegnil večjo pozornost pri vseh značilno ocenjenih konceptnih dvojicah predlogov. Rezultati potrjujejo, da je pretirana uporaba novih možnosti osvetlitve estetsko manj privlačna. Veliko detajlov anketiranim manj ugaja v primeru osvetlitve Parka slovenske reformacije. Tu se jim zdi prijetnejši enotnejši in svetlobno skladnejši ploskovni koncept. To se sklada s spoznanji iz obstoječe literature in z izsledki preteklih raziskav. Ünver (2009) potrjuje, da na mnenje o osvetlitvi urbanih parkov močno vpliva kriterij kontrasta. Neenakomerna porazdelitev svetlosti in močne sence lahko ustva- rijo pretirano dramatičnost in neprijazen videz krajinskih objektov. Senca kot arhitekturni element bistveno vpliva na človekovo dojemanje in doživljanje prostora (Kastelic idr., 2012). Maria Johansson idr. (2011) ugotavljajo, da se morajo pešpoti v parkih zdeti obiskovalcem dovolj svetle tako s stališča vidne dostopnosti kot občutka »prijetnosti «, da tako osvetlitev ocenijo za ustrezno. Raziskave kažejo, da lahko tudi uporaba ustreznih LED-nadomestkov izboljša omenjena kriterija (Kuhn idr., 2013). Pri parku bi lahko bil vzrok za primernejšo izbiro ploskovnega koncepta pred detajlnim tudi videz oken OLED. Ta opazovalcu verjetno dajejo občutek ločenosti med »notranjim « in »zunanjim « mestnim življenjem in težko upravičijo svojo vlogo pri izboljšanju podobe mesta. V članku ugotavljamo, da je izbira ploskovnega koncepta značilna pri spremenljivki vidne orientacije za večino lokacij. Le v primeru Trnovskega pristana so glede te spremenljivke rezultati izbire koncepta približno enaki. Vzrok za to je verjetno na splošno svetlejši in enakomernejši ploskovni koncept. Spremenljivko vidna dostopnost literatura napoveduje z vidnim poljem, okoljskim zaupanjem in občutkom svetlosti (Johansson idr., 2011). To pojasnjuje povezavo med občutkom svetlosti predlogov osvetlitve in mnenjem o zmožnosti vidne orientacije $\mathrm{v}$ tako osvetljenem prostoru. $\mathrm{V}$ pravem prostoru človek pridobiva prostorske informacije s perifernim oziroma $\mathrm{z} \gg$ retinalnim « vidom (ang. retinal vision) (Liljefors, 1999). Pri opazovanju slik deluje predvsem centralni vid, ki nam daje informacije o detajlih. $\mathrm{V}$ članku obravnavana spremenljivka vidna orientacija $\mathrm{v}$ osvetljenem prostoru je zato le mnenje o vidni preglednosti prikazanih osvetlitev. Ker se tehnologija 
računalniških zaslonov poslužuje različnih tehničnih rešitev, moramo omeniti možnost različne svetlosti zaslonov, prek katerih so anketirani izpolnjevali anketo. Poleg tega je verjetno, da so imeli anketirani različno nastavljene svetlosti zaslonov oziroma so bili med izpolnjevanjem ankete $\mathrm{v}$ različno osvetljenih prostorih. Ti dejavniki bi lahko v manjši meri vplivali na ocene »prijetnosti《 in »pozornosti« predlogov osvetlitev. Zaradi teh dejavnikov v članku prav tako nismo obravnavali vpliva spremenljivke korelirana barvna temperatura na ocene prihodnje predloge osvetlitve. Casciani in Rossi (2012) v svoji raziskavi ugotavljata, da so bili glede »prijetnosti《 in »pozornosti« najbolje ocenjeni primeri, ki prikazujejo neobičajen pristop k osvetlitvi prostora in aktivno vključujejo uporabnike. $S$ tem dokazujeta obstoj naraščajoče potrebe po doživljanju mest $\mathrm{z}$ vidika družbenih odnosov. Podobno kot Ünver (2009) opažata močan vpliv barv na mnenje o privlačnosti osvetlitve. LED- in OLED-svetila imajo glede uporabe enobarvne svetlobe velik potencial, vendar smo se v članku njihovi umestitvi pri proučevanju prihodnjih predlogov osvetlitve namensko izognili. Začetno zanimanje za barvno osvetlitev običajno hitro mine. Uporabniki se take osvetlitve tudi hitreje naveličajo, zato je priporočljiva le za kratkotrajne dekorativne namene. Ocene spremenljivk estetika in primernost potrjujejo njuno precejšnjo korelacijo. Ta odstopa le pri osvetlitvi Ajdovščine, pri kateri je sicer več anketirancev ocenilo detajlni koncept za bolj estetski, vendar se jim je zdel ploskovni koncept tu primernejši. Najznačilnejša glede estetike je preferenčna izbira detajlnega koncepta osvetlitve pri lokaciji Trnovski pristan. Estetske presoje zadevajo razlago in kategorizacijo tega, kar vidimo, zato pomenijo več kot le čustvene odzive (glej Veitch, 2001). Stephen Kaplan (1979) svoj funkcionalni pristop h krajinski estetiki opiše z ocenami dimenzij koherence, berljivosti, skrivnostnosti in kompleksnosti. Ustrezna kombinacija teh dimenzij je zelo verjetno vzrok za tako številno izbiro predlagane osvetlitve pri Trnovskem pristanu. Nove možnosti uporabe LED- in OLED-svetil lahko pomenijo povečanje števila novih aplikacij, posledica tega pa so povečana poraba električne energije, večji stroški in večje onesnaženje okolja. Postavitev OLED-svetil na pročelja stavb ne bi bila preprosta naloga. Površina pročelij ni ravna, veliko težavo bi pomenilo ustrezno združevanje posameznih modulov OLED po svetilnosti in barvi svetlobe, ki bi jo izsevali. Modulom se jakost svetlobnega toka zmanjšuje različno in neenakomerno. Uravnavanje tega bi morala prevzeti kakovostna regulacijska elektronika. To ni preprosto, ker človeško oko zazna že majhne razlike $\mathrm{v}$ kontrastu, ki pa niso odvisne le od svetlosti posameznega vira, temveč tudi od spektralne porazdelitve svetlobe, ki jo ta izseva. Vzdrževanje takega sistema bi bilo zapleteno. Začetek uporabe prihodnjih funkcionalnih ambientalnih svetil OLED za zunanje prostore bo verjetno diskretna in nežna OLED-osvetlitev detajlov, kot so hišne številke in imena ulic. Razvoj in umestitev LED- in OLED-svetil v urbani prostor morata biti hkrati skladna z načeli mezopske fotometrije (glej na primer Ylinen idr., 2010). Le tako je mogoče dobiti energetsko in vidno učinkovitejšo zunanjo razsvetljavo. Pri umestitvi svetil v prostor je zelo pomembna tudi problematika svetlobnega onesnaženja. Obravnava obsega problem splošne preosvetljenosti urbanih prostorov ponoči, problem uhajanja odvečnega svetlobnega toka v nebo in okolico, bleščanje in vprašanje uporabe svetlobnih virov $s$ primernimi spektralnimi značilnostmi. Raziskave ugotavljajo, da zunanja osvetlitev vpliva na delovanje človekovega cirkadialnega sistema glede nočnega tvorjenja melatonina (Rea idr., 2010). Vpliv v primeru praktičnih aplikacij je opaznejši predvsem pri uporabi zelo »hladno belih « virov svetlobe. LED-viri bele svetlobe $\mathrm{z}$ izrazitim vrhom spektralne porazdelitve jakosti sevanja v krajšem delu spektra v primerjavi z visokotlačnimi natrijevimi sijalkami povečajo sij neba od $10 \%$ do $20 \%$ (Bierman, 2012). Vendar pa so danes na voljo tudi kakovostna in učinkovita LED-svetila z nizkimi koreliranimi temperaturami barv oziroma $\gg$ toplo belo « barvo izsevane svetlobe. V nekaterih novejših raziskavah se proučujejo tudi vplivi spektralne porazdelitve bližnjega svetlečega ozadja na bleščanje LED-svetlobnih virov (glej Sweater-Hickcox idr., 2013). K znižanju porabe polprevodniških virov svetlobe električne energije in zmanjšanju svetlobnega onesnaženja pa bi lahko pripomogli s pametno regulacijo njihovega delovanja.

$S$ člankom želimo poudariti, da je treba pri prehodu na nove tehnologije svetil celostno razmisliti o pomenu osvetlitve mesta in omenjeni prehod izkoristiti tudi za izboljšanje videza mesta. Le v celoti skladna, dobro premišljena in lokaciji primerna inovativna umestitev svetil LED in OLED v urbani prostor bi pozitivno vplivala na podobo mesta v očeh uporabnikov. Ugotovitve raziskave naj služijo kot izhodišče za nadaljnje študije o inovativni in smotrni uporabi novih tehnologij svetil v urbanem prostoru. Članek je del širše raziskave, $\mathrm{v}$ kateri smo med drugim raziskovali tudi odvisnost ocen spremenljivk in izbire predlogov osvetlitve od starosti anketiranih oseb ter ugotavljali, ali anketirani drugače ocenjujejo predlagane koncepte, če so svetlobne rešitve konceptov prikazane $\mathrm{z}$ večjimi slikami in so podrobneje razložene. Poleg tega je bila narejena tudi okvirna napovedno primerjalna analiza porabe električne energije med prihodnjima konceptoma osvetlitve na posameznih lokacijah.

\section{Sklep}

V članku je predstavljen prvi primer raziskave prihodnje osvetlitve na podlagi LED- in OLED-virov svetlobe in njenega vpliva na nočno podobo mesta, zato menimo, da prispeva $\mathrm{k}$ teoriji osvetljevanja urbanega prostora $s$ specifičnim interdisciplinarnim pristopom. Ta združuje inovativne tehnične in arhitekturne prvine $\mathrm{z}$ raziskavo javnega mnenja, ki izhaja iz teoretskih osnov okoljske psihologije. Rezultati kažejo, da bi predlagane možnosti uporabe polprevodniških svetil pri ve- 
čini obravnavanih lokacij v povprečju vplivale na mnenje o podobi tako osvetljenega urbanega prostora v pozitivni smeri, pri čemer se ocene $»$ prijetnosti in $»$ pozornosti $\ll$ predlogov osvetlitve med konceptoma značilno razlikujejo. V članku nam je uspelo odgovoriti na glavno raziskovalno vprašanje, vendar se moramo ob tem zavedati tudi drugih ugotovljenih vplivov, kot je na primer vpliv lokacije na ocene anketirancev, začetnih domnev in določenih omejitev raziskovalne metode. Pri tem ponovno poudarjamo, da predlagana prihodnja osvetlitev pri obeh konceptih poskuša bolje povezati tudi kompozicijsko enotnost prostora in obnoviti strukturne značilnosti mesta. Namestitev novih tehnologij svetil lahko pripomore $\mathrm{k}$ izboljšanju nočne podobe mesta, vendar pa mora biti v skladu $\mathrm{z}$ estetskimi načeli urbane osvetlitve, ki izražajo uravnotežen sistem hierarhij in razlik v prostoru (Brandi in Geissmar-Brandi, 2007), ter biti primerna za mestno lokacijo in identiteto mesta. Prihodnje raziskave bi se lahko osredotočile na umestitev samo ene vrste rešitev $s$ polprevodniškimi svetili in na primerjavo njenega vpliva na različnih lokacijah. Mnenja o podobi mesta bi se lahko proučevala tudi v primerjavi obstoječe in prihodnje osvetlitve. Ko bo tehnološko izvedljivo, bo mogoče proučevati vplive inovativne umestitve OLED-svetil v pravem urbanem prostoru. Možnosti uporabe LED- in OLED-svetil v urbanem prostoru so resnično zelo številne, vendar pa prav vse niso upravičene niti sprejemljive glede številnih drugih značilnosti, potreb in zahtev urbanega načrtovanja osvetlitve. Preudarno načrtovanje, ki upošteva dejavnike različnih področij urbane osvetlitve, je torej predpogoj za ustvarjanje trajnostnih rešitev mestne razsvetljave, s katerimi bi lahko povečali pozitivne učinke novih tehnologij svetil na mesta in njihove uporabnike in zmanjšali negativne, ob tem pa hkrati pripomogli k oblikovanju prihodnje nočne podobe mest.

\section{Simon Rankel}

Univerza v Ljubljani, Fakulteta za gradbeništvo in geodezijo, Interdisciplinarni podiplomski študij prostorskega in urbanističnega planiranja, Slovenija

E-pošta: simon.rankel@siol.net

\section{Viri in literatura}

Ab. Jalil, N., Yunus, R. M., in Said., N. S. (2012): Environmental colour impact upon human behaviour: A review. V: Abbas, M. Y., Bajunid, A. F. I., in Azhari, N. F. N. (ur.): Proceedings of Asia Pacific Conference on Environment-Behaviour Studies, str. 54-62. Farmagusta, Procedia - Social and Behavioral Sciences.

Bačlija, I. (2011): Urbani menedžment v evropskem kontekstu. Urbani izziv, 22(2), str. 64-74. DOI: 10.5379/urbani-izziv-2011-22-02-006

Bandur, S. (2012): Podhod Ajdovščina - kronično pozabljeno podzemlje. Delo, 54(10), 12. 1. 2012.

Bierman, A. (2012): Will switching to LED outdoor lighting increase sky glow? Lighting Research and Technology, 44(4), str. 449-458. DOI: $10.1177 / 1477153512437147$

Bizjak, I. (2012): Izboljšanje javne participacije pri prostorskem na-
Črtovanju s pomočjo orodij spleta 2.0. Urbani izziv, 23(1), str. 36-48. DOI: 10.5379/urbani-izziv-2012-23-01-004

Brandi, U., in Geissmar-Brandi, C. (2007): Light for cities, lighting design for urban spaces. A Handbook. Hamburg, Birkhäuser.

Casciani, D., in Rossi, M. (2012): ELSE, Experience of lighting sustainability in the environment. Prispevek je bil predstavljen na konferenci, z naslovom Cumulus Conference Nothern World Mandate - Towards Open and Participative Cities, ki je potekala od 24. do 26. maja v Helsinkih na Finskem. Tipkopis.

Chiang, C., Winscom, C., Bull, S., in Monkman, A. (2009): Mechanical modeling of flexible OLED devices. Organic Electronics, 10(7), str. 12681274. DOI: $10.1016 /$ j.orgel.2009.07.003

Flynn, J. E., Hendrick, C., Spencer, T., in Martyniuk, O. (1979): A guide to methodology procedures for measuring subjective impressions in lighting. Journal of IES, 8(2), str. 95-110.

Gardner, C. (2006): The use and misuse of coloured light in the urban environment. Optics \& Laser Technology, 38(4-6), str: 366-376. DOI: 10.1016/j.optlastec.2005.06.022

Gibson, J. J. (1971): The information available in pictures. Leonardo, 4(1), str. 27-35. DOI: $10.2307 / 1572228$

Grover, R., Srivastava, R., Omwati, R., Mehta, D. S., in Kamalasanan, M. N. (2011): New organic thin-film encapsulation for organic light emitting diodes. Journal of Encapsulation and Adsorption Sciences, 1(2), str. 23-28. DOI: 10.4236/jeas.2011.11003

Ho, D. C. W., Yau, Y., Law, Poon, S. W., Yip, H. K., in Liusman, E. (2012): Socialna zdržnost pri urbani prenovi: ocena želja skupnosti. Urbani izziv 23(1), str. 49-63. DOI: 10.5379/urbani-izziv-2012-23-01-005

Hohl-Abi Chedid, A. (2012): Philips provides OLED outlook at the LED show. LEDs Magazine industry news, 31.07.2012. Dostopno na: http:// ledsmagazine.com (sneto 22. 10. 2012).

Joels, D. (2006): Lighting design for urban spaces: Connecting light qualitites and urban planning concepts. Magistrsko delo. Stockholm, KTH Royal Institute of Technology, School of Technology and Health, Architectural Lighting Design.

Johansson, M., Rosén, M., in Küller, R. (2011): Individual factors influencing the assessment of the outdoor lighting of an urban footpath. Lighting Research and Technology, 43(1), str. 31-43. DOI: $10.1177 / 1477153510370757$

Johansson, M., Pedersen, E., Maleetipwan-Mattson, P., Kuhn, L., in Laike, T. (2013): Perceived outdoor lighting quality (POLQ): A lighting assessment tool. Journal of Environmental Psychology. DOI: 10.1016/ j.jenvp.2013.12.002

Kaplan, S. (1979): Perceptions and Landscape: Conceptions and Misconceptions. V: Elsner, G. H, in Smardon, R. C. (ur.): Proceedings of Our national landscape, str. 241-248. Incline Village, United States Department of Agriculture.

Kastelic, J., Novljan, T., in Vodopivec, A. (2012): Učinek sence pri snovanju, zaznavanju in doživljanju arhitekturnega prostora. AR ahitektura, raziskave, $2-3$, str. $18-27$.

Kennedy, J. M. (1974): A psychology of picture perception. San Francisco, Jossey-Bass Publishers.

Kennedy, S. (2005): Escaping the bulb culture: The future of LEDs in architectural illumination. LEDs Magazine, 1(1), str. 13-15.

Kim, I., Choi, A., in Jeong, J. (2012): Precise control of a correlated color temperature tunable luminaire for a suitable environment. Building and Environment, 57, str. 302-312. DOI: 10.1016/j.buildenv.2012.06.001

Kostic, A., in Djokic, L. (2013): Subjective impressions under LED and metal halide lighting. Lighting Research and Technology. DOI: $10.1177 / 1477153513481037$ 
Kuhn, L., Johansson, M., Laike, T., in Govén, T. (2013): Residents' perceptions following retrofitting of residential area outdoor lighting with LEDs. Lighting Research and Technology, 45(5), str. 568-584. DOI: $10.1177 / 1477153512464968$

Küller, R., Ballal, S., Laike, T., Mikellides, B., in Tonello, G. (2006): The impact of light and colour on pyschologial mood: A cross-cultural study of indoor work environments. Ergonomics, 49(14), str. 1496-1507. DOI: 10.1080/00140130600858142

Lee, J., Hofmann, S., Furno, M., Thomschke, M., Kim, Y. H., Lüssem, B., in Leo., K. (2011): Systematic investigation of transparent organic light-emitting diodes depending on top metal electrode thickness. Organic Electronics, 12(8), 1383-1388. DOI: 10.1016/j.orgel.2011.05.006

Legge, G. E., Yu, D., Kallie, C. S., Bochsler, T. M., in Gage, R. (2010): Visual accessibility of ramps and steps. Journal of Vision, 10(11) str. 1-19. DOI: $10.1167 / 10.11 .8$

Liljefors, A. (1999): Lighting - visually and physically. Stockholm, KTH Lighting Department.

Lynch, K. (2010): Podoba mesta (The image of the city). Novo mesto, Založba Goga.

Mayhoub, M. S., in Carter, D. J. (2012): Hybrid lighting systems: Performance and design. Lighting Research and Technology, 44(3), str. 261276. DOI: $10.1177 / 1477153511416324$

McKinsey \& Company (2012): Lighting the way: Perspectives on the global lighting market. Vienna, München.

Neumann, A., Wierer, J. J., Jr., Davis, W., Ohno, Y., Brueck, S. R. J., in Tsao, J. Y. (2011): Four-color laser white illuminant demonstrating high color-rendering quality. Optics Express, 19(S4), str. A982-A990. DOI: 10.1364/OE.19.00A982

Novljan, T. (2008): Svetlobno degradirani arhitekturni ambienti. $A R$ ahitektura, raziskave, 9(2), str. 86-91.

Odlok o razglasitvi spomenikov naravne in kulturne dediščine na območju občine Ljubljana Center med Aškerčevo, Tivolsko in Slovensko cesto. Uradni list Republike Slovenije, št. 60/1993. Ljubljana.

Parandian, A., in Rip, A. (2013): Scenarios to explore the futures of the emerging technology of organic and large area electronics. European Journal of Futures Research, 15(9), str. 1-18. DOI: 10.1007/s40309-0130009-2

Prosenc., D. M., in Potočnik, T. (2011): Konservatorski načrt za prenovo Aškerčeva, Tivolska, Slovenska (OPPN 106 - Kolizej) v Ljubljani. Projektna naloga. Ljubljana, Populus Prostorski inženiring d.o.o.

Rea, M. S., Bullough, J. D., in Akashi, Y. (2009): Several views of metal halide and high-pressure sodium lighting for outdoor applications. Lighting Research and Technology, 41(1), str. 297-320. DOI: $10.1177 / 1477153509102342$

Rea, M. S., Smith, A., Bierman, A., in Figueiro, M. G. (2010): The potentia of outdoor lighting for stimulating the human circadian system. Raziskovalno poročilo. Troy, Lighting Research Center, Rensselaer Polytechnic Institute.

Rehan, R. M. (2013): Sustainable streetscape as an effective tool in sustainable urban design. HBRC Journal, 9(2), str. 173-186. DOI: 10.1016/ j.hbrcj.2013.03.001

Russell, J. A. (1980): A circumplex model of affect. Journal of Personality and Social Psychology, 39(6), str. 1161-1178. DOI: 10.1037/h0077714

Russell, J. A. (2003): Core affect and the psychological construction of emotion. Psychological Review, 110(1), str. 145-172. DOI: 10.1037/0033295X.110.1.145
Sašek Divjak, M. (2008): Urbanistično načrtovanje strateškega prostorskega razvoja Ljubljane. Urbani izziv, 19(1), str. 11-24. DOI: 10.5379/ urbani-izziv-2008-19-01-002

Schmidt, J. A., in Töllner, M. (2006): Stadtlicht, Lichtkonzepte für die Stadgestaltung. Stuttgart, Fraunhofer IRB Verlag.

Schwamb, P., Reusch, T. C. G., in Brabec, J. (2013): Passive cooling of large-area organic light-emitting diodes. Organic Electronics, 14(8), str. 1939-1945. DOI: 10.1016/j.orgel.2013.04.023

Slawinski, M., Wingarten, M., Heuken, M., Vescan, A., in Kalisch, H. (2013): Investigation of large-area OLED devices with various grid geometries. Organic Electronics, 14(10), str. 2387-2391. DOI: 10.1016/j. orgel.2013.06.003

Sweater-Hickcox, K., Narendran, N., Bullough, J. D., in Freyssinier, J. P. (2013): Effect of different coloured luminous surrounds on LED discomfort glare perception. Lighting Research and Technology, 45(4), str. 464-475. DOI: 10.1177/1477153512474450

Uredba o mejnih vrednostih svetlobnega onesnaževanja okolja. Uradni list Republike Slovenije, št. 81/2007. Ljubljana.

Ünver, A. (2009): People's experience of urban lighting in public space. Magistrsko delo. Ankara, Middle East Technical University, City and regional planning.

Veitch, J. A. (2001): Psychological processes influencing lighting quality. Journal of the Illuminating Engineering Society, 30(1), str. 124-140. DOI: 1 $0.1080 / 00994480.2001 .10748341$

Ylinen, A., Puolakka, M., in Halonen, L. (2010): Impact of mesopic design on outdoor lighting energy efficiency. V: Proceedings of CIE 2010 Lighting quality and energy efficiency, str. 475-481. Dunaj, Commission Internationale de L'Eclairage.

Zakon o varstvu kulturne dediščine. Uradni list Republike Slovenije, št. 16/2008. Ljubljana. 